\author{
B.J. Kadirkulov ${ }^{1, *}$, M.A. Jalilov ${ }^{2}$ \\ ${ }^{1}$ Tashkent State University of Oriental Studies, Tashkent, Uzbekistan; \\ ${ }^{2}$ Ferghana State University, Ferghana, Republic of Uzbekistan \\ (E-mail:kadirkulovbj@gmail.com, alimuhammad9978@mail.ru)
}

\title{
On a nonlocal problem for a fourth-order mixed-type equation with the Hilfer operator
}

\begin{abstract}
The present work is devoted to the study of the solvability questions for a nonlocal problem with an integrodifferential conjugation condition for a fourth-order mixed-type equation with a generalized RiemannLiouville operator. Under certain conditions on the given parameters and functions, we prove the theorems of uniqueness and existence of the solution to the problem. In the paper, given example indicates that if these conditions are violated, the formulated problem will have a nontrivial solution. To prove uniqueness and existence theorems of a solution to the problem, the method of separation of variables is used. The solution to the problem is constructed as a sum of an absolutely and uniformly converging series in eigenfunctions of the corresponding one-dimensional spectral problem. The Cauchy problem for a fractional equation with a generalized integro-differentiation operator is studied. A simple method is illustrated for finding a solution to this problem by reducing it to an integral equation equivalent in the sense of solvability. The authors of the article also establish the stability of the solution to the considered problem with respect to the nonlocal condition.
\end{abstract}

Keywords: mixed-type equation, nonlocal boundary value problem, the existence and uniqueness of a solution, fractional differentiation operator, the Hilfer operator, the Mittag-Leffler function.

\section{Introduction and Problem Statement}

Let $\Omega=\{(x, t): 0<x<1,-a<t<b\}, \Omega_{1}=\Omega \cap(t>0), \Omega_{2}=\Omega \cap(t<0)$, where $a, b$ are positive real numbers. Considering this domain for the mixed-type equation

$$
0=\left\{\begin{array}{l}
\frac{\partial^{4} u}{\partial x^{4}}+D^{\alpha, \gamma} u, t>0, \\
\frac{\partial^{4} u}{\partial x^{4}}+\frac{\partial^{2} u}{\partial t^{2}}, t<0,
\end{array}\right.
$$

the following nonlocal problem is considered.

Problem $A$. To find the function $u(x, t)$, which belongs to the class

$$
t^{1-\gamma} D^{\alpha, \gamma} u, t^{1-\gamma} \frac{\partial^{k} u}{\partial x^{k}} \in C\left(\bar{\Omega}_{1}\right), \frac{\partial^{k} u}{\partial x^{k}} \in C\left(\bar{\Omega}_{2}\right), u_{t t} \in C\left(\Omega_{2}\right), u_{x x x x} \in C\left(\Omega_{1} \cup \Omega_{2}\right),
$$

where $k=\overline{0,2}$, satisfies equation (1) in the domain $\Omega_{1} \cup \Omega_{2}$, the boundary conditions

$$
\begin{gathered}
u(0, t)=u(1, t)=u_{x x}(0, t)=u_{x x}(1, t)=0, t \in[-a, 0] \cup(0, b], \\
u_{t}(x,-a)=D^{\alpha, \gamma} u(x, b)+\varphi(x), 0 \leq x \leq 1,
\end{gathered}
$$

and the gluing conditions

$$
\lim _{t \rightarrow+0} J_{0+}^{1-\gamma} u(x, t)=\lim _{t \rightarrow-0} u(x, t), \lim _{t \rightarrow+0} J_{0+}^{1-\alpha} \frac{d}{d t} J_{0+}^{1-\gamma} u(x, t)=\lim _{t \rightarrow-0} u_{t}(x, t) .
$$

\footnotetext{
* Corresponding author.

E-mail: kadirkulovbj@gmail.com
} 
Here $\varphi(x)$ is a given sufficiently smooth function, $D^{\alpha, \gamma}, 0<\alpha \leq \gamma \leq 1$ is a generalized fractional differentiation operator (the definition of this operator is provided below).

For a function $\varphi(t)$, given on $(a, b),-\infty<a<b<\infty$, the expression

$$
I_{a+}^{\alpha} \varphi(x)=\frac{1}{\Gamma(\alpha)} \int_{a}^{x}(x-t)^{\alpha-1} \varphi(t) d t, x \in(a, b)
$$

is said to be the fractional Riemann-Liouville integral of the order $\alpha>0$ [1, Vol. 1, p. 25]. Here $\Gamma(\alpha)$ is the Euler gamma function. Let $n-1<\alpha \leq n, n \in N$. The fractional Riemann-Liouville derivative of a function $\varphi(t)$ of the order $\alpha$ is defined by the formula [1, Vol. 1, p. 27]:

$$
D_{a+}^{\alpha} \varphi(x)=\frac{d^{n}}{d x^{n}} I_{a+}^{n-\alpha} \varphi(x), x \in(a, b)
$$

The fractional Caputo derivative of a function $\varphi(t)$ of the order $\alpha$ is defined as follows [1, Vol. 1, p. 34]:

$$
{ }_{*} D_{a+}^{\alpha} \varphi(x)=I_{a+}^{n-\alpha} \varphi^{(n)}(x)=\frac{1}{\Gamma(n-\alpha)} \int_{a}^{x} \frac{\varphi^{(n)}(t) d t}{(x-t)^{\alpha-n+1}} .
$$

For $\alpha=n \in N$, these derivatives are reduced to the derivatives of integer order [1, Vol. 1, p. 27, 34]:

$$
D_{a+}^{n} \varphi(x)={ }_{*} D_{a+}^{n} \varphi(x)=\frac{d^{n} \varphi}{d x^{n}} .
$$

The generalized Riemann-Liouville derivative of the fractional order $\alpha, n-1<\alpha \leq n, n \in N$ and type $\beta$, $0 \leq \beta \leq 1$ (otherwise, the Hilfer fractional deivative) of a function $f(t)$ is defined by the formula

$$
D_{a+}^{\alpha, \beta} \varphi(x)=I_{a+}^{\beta(n-\alpha)} \frac{d^{n}}{d x^{n}} I_{a+}^{(1-\beta)(n-\alpha)} \varphi(x) .
$$

Hence, it follows that for $\beta=0$ the Hilfer fractional deivative coincides with the Riemann-Liouville operator $\left(D_{a+}^{\alpha, 0}=D_{a+}^{\alpha}\right)$, and in the case of $\beta=1$, we obtain the fractional Caputo derivative, that is $D_{a+}^{\alpha, 1}={ }_{*} D_{a+}^{\alpha}$.

Thus, the operator $D^{\alpha, \gamma}$ is a continuous interpolation of the well-known Riemann-Liouville and Caputo differentiation operators of fractional order.

Further, for the convenience of notation, we will use another notation for the Hilfer fractional derivative, i.e., $D^{\alpha, \gamma}=D_{a+}^{\alpha, \beta}$ where $\gamma=\alpha+\beta n-\alpha \beta$ and $\alpha \leq \gamma \leq n$.

The generalized operator $D^{\alpha, \gamma}$ was first introduced by Hilfer [2]. Applying the integral transforms of Fourier, Laplace, and Mellin, he investigated the Cauchy problem for the diffusion equation with a generalized operator $D^{\alpha, \gamma}$, the solution of which was represented in terms of the Fox H-functions.

In [3], boundary value problems were investigated for the fractional diffusion equation with a time generalized fractional Riemann-Liouville derivative. To solve the problem, in the finite domain, the Laplace method of separation of variables and transform was used. The solution was obtained in the form of an infinite series containing the Mittag-Leffler functions, and the asymptotic behavior of the solution was found at infinity. In an infinite domain with respect to a spatial variable, using the Fourier-Laplace transform method, the Cauchy problem was solved, and the fundamental solution to the Cauchy problem was found.

In [4], analytical and numerical solutions of boundary value problems were investigated for the fractional diffusion equation with fractional Hilfer time derivative and spatial fractional Riesz-Feller derivative. The Laplace and Fourier transform methods were applied to solve the problem, and solutions were presented using the Mittag-Leffler functions and Fox H-functions. The numerical solution of the problem was also considered by approximating fractional derivatives with fractional Grunwald-Letnikov derivatives.

In [5], the properties of the Hilfer operator were investigated in a special functional space, and an operational method was developed for solving fractional differential equations with this operator in the same space. Elaborating the results of [5], the authors of [6] developed an operational method for solving fractional differential equations containing a finite linear combination of the Hilfer operators.

In [7], the source identification problem was investigated for the generalized diffusion equation with the generalized integro-differentiation operator. We also note the work [8], where inverse problems were studied for a generalized fourth-order parabolic equation with the operator $D^{\alpha, \gamma}$. 
Note that various models of practical problems using fractional calculus are constructed in [1], [9-12]. More detailed information, as well as a bibliography on the Hilfer fractional derivative and its properties, can be found in the monograph [13], where the theory of fractional integro-differentiation, including the Hilfer fractional derivative, is systematically presented.

Nonlocal problems are arisen in the study of various problems of mathematical biology, forecasting soil moisture, physics, and plasma problems. More detailed information on nonlocal problems can be found in the monograph [14]. With regard to nonlocal problems for mixed-type equations, significant results in this direction were obtained by K.B. Sabitov and his students [15-18]. Note that a nonlocal condition of type (3) takes place when simulating the problems of flow around airfoils by a flow of subsonic velocity with a supersonic zone [15]. It should also be noted the papers [19], [20], where nonlocal problems for equations of mixed type with the generalized in time fractional Riemann-Liouville derivative were studied.

In this paper, we study a nonlocal boundary value problem for a mixed-type equation with a Hilfer operator of fractional order, which is a further development and generalization of the results from [16], [21].

\section{On the solution of the Cauchy problem for a fractional-order equation with the Hilfer operator}

Consider the Cauchy problem for a fractional-order differential equation with the operator $D^{\alpha, \gamma}$

$$
\left\{\begin{array}{c}
D^{\alpha, \gamma} u(t)=\lambda u(t)+f(t), t \in(0, \ell) \\
\lim _{t \rightarrow+0} \frac{d^{k}}{d t^{k}} J_{0+}^{n-\gamma} u(t)=u_{k}, k=0,1, . . n-1
\end{array}\right.
$$

where $f(t)$ is a given function, $u_{k}=$ const.

It should be noted that in [7], the Laplace method was used to solve this problem, and in [5], the solution of a more general problem in a special functional space was found applying the operational calculus. Here, in contrast to these works, we will show one simple way to solve the problem, which makes it possible to obtain the solution to this problem in an explicit form.

The following takes place:

Lemma 1. Let $t^{1-\gamma} f(t) \in C[0, \ell]$. Then a solution to problem (6) exists, is unique, belongs to the class $t^{1-\gamma} D^{\alpha, \gamma} u(t) \in C[0, \ell]$, and is represented in the form

$$
u(t)=\sum_{k=0}^{n-1} u_{k} t^{\gamma+k-n} E_{\alpha, \gamma+k+1-n}\left(\lambda t^{\alpha}\right)+\int_{0}^{t}(t-\tau)^{\alpha-1} E_{\alpha, \alpha}\left(\lambda(t-\tau)^{\alpha}\right) f(\tau) d \tau .
$$

Here $E_{\alpha, \beta}(z)$ is the Mittag-Leffler function, which has the form [22; 117], [1, Vol 1; 269]

$$
E_{\alpha, \beta}(z)=\sum_{k=0}^{\infty} \frac{z^{k}}{\Gamma(\alpha k+\beta)}, z, \alpha, \beta \in C, \operatorname{Re}(\alpha)>0 .
$$

Proof. Taking into account the definition of the Hilfer operator, one can write the fractional-order differential equation corresponding to problem (6) in the following form:

$$
J_{0+}^{\gamma-\alpha} D_{0+}^{\gamma} u(t)=\lambda u(t)+f(t) .
$$

Further, applying the operator $J_{0+}^{\alpha}$ to both sides of this equation, taking into account the linearity of $J_{0+}^{\alpha}$, and also the formula $[23 ; 75]$

$$
J_{0+}^{\delta} D_{0+}^{\delta} u(t)=u(t)-\sum_{k=0}^{n-1} \frac{t^{\delta+k-n}}{\Gamma(\delta+k+1-n)} \lim _{x \rightarrow 0} \frac{d^{k}}{d t^{k}} J_{0+}^{n-\delta} u(t), \delta \in(n-1, n],
$$

we obtain

$$
u(t)-\sum_{k=0}^{n-1} \frac{t^{\gamma+k-n} u_{k}}{\Gamma(\gamma+k+1-n)}=\lambda J_{0+}^{\alpha} u(t)+J_{0+}^{\alpha} f(t) .
$$

Thus, we have reduced the solution of problem (6) to the solution of the Volterra integral equation of the second kind of the form (8). 
Further, using Theorem 3.1 from [22; 123], we represent a solution of equation (8) in the form

$$
\begin{gathered}
u(t)=\sum_{k=0}^{n-1} \frac{t^{\gamma+k-n} u_{k}}{\Gamma(\gamma+k+1-n)}+J_{0+}^{\alpha} f(t)+ \\
+\lambda \int_{0}^{t}(t-\tau)^{\alpha-1} E_{\alpha, \alpha}\left(\lambda(t-\tau)^{\alpha}\right)\left[\sum_{k=0}^{n-1} \frac{\tau^{\gamma+k-n} u_{k}}{\Gamma(\gamma+k+1-n)}+J_{0+}^{\alpha} f(\tau)\right] d \tau .
\end{gathered}
$$

Denote

$$
\begin{gathered}
I_{1}(t)=\sum_{k=0}^{n-1} \frac{u_{k}}{\Gamma(\gamma+k+1-n)}\left(t^{\gamma+k-n}+\lambda \cdot \int_{0}^{t}(t-\tau)^{\alpha-1} E_{\alpha, \alpha}\left(\lambda(t-\tau)^{\alpha}\right) \tau^{\gamma+k-n} d \tau\right), \\
I_{2}(t)=J_{0+}^{\alpha} f(t)+\lambda \cdot \int_{0}^{t}(t-\tau)^{\alpha-1} E_{\alpha, \alpha}\left(\lambda(t-\tau)^{\alpha}\right) J_{0+}^{\alpha} f(\tau) d \tau .
\end{gathered}
$$

Changing variables by the formula $s=t-\tau$, using formulas [22]

$$
\begin{gathered}
E_{\alpha, \mu}(z)=\frac{1}{\Gamma(\mu)}+z \cdot E_{\alpha, \mu+\alpha}(t), \alpha>0, \mu>0, \\
\frac{1}{\Gamma(\nu)} \int_{0}^{z}(z-t)^{\nu-1} E_{\alpha, \beta}\left(\lambda t^{\alpha}\right) t^{\beta-1} d t=z^{\beta+\nu-1} \cdot E_{\alpha, \beta+\nu}\left(\lambda z^{\alpha}\right), \nu>0, \beta>0,
\end{gathered}
$$

the first integral can be easily reduced to the form

$$
I_{1}(t)=\sum_{k=0}^{n-1} u_{k} t^{\gamma+k-n} E_{\alpha, \gamma+k+1-n}\left(\lambda t^{\alpha}\right) .
$$

Further, transform the second term in the expression for $I_{2}(t)$ to the form

$$
\begin{gathered}
\int_{0}^{t}(t-\tau)^{\alpha-1} E_{\alpha, \alpha}\left(\lambda(t-\tau)^{\alpha}\right) J_{0+}^{\alpha} f(\tau) d \tau= \\
=\frac{1}{\Gamma(\alpha)} \int_{0}^{t}(t-\tau)^{\alpha-1} E_{\alpha, \alpha}\left(\lambda(t-\tau)^{\alpha}\right) d \tau \int_{0}^{\tau}(\tau-s)^{\alpha-1} f(s) d s= \\
=\frac{1}{\Gamma(\alpha)} \int_{0}^{t} f(s) d s \int_{s}^{t}(t-\tau)^{\alpha-1}(\tau-s)^{\alpha-1} E_{\alpha, \alpha}\left(\lambda(t-\tau)^{\alpha}\right) d \tau .
\end{gathered}
$$

Taking into account formula (11), we represent the inner integral in the form

$$
\int_{s}^{t}(t-\tau)^{\alpha-1}(\tau-s)^{\alpha-1} E_{\alpha, \alpha}\left(\lambda(t-\tau)^{\alpha}\right) d \tau=\Gamma(\alpha)(t-\tau)^{2 \alpha-1} E_{\alpha, 2 \alpha}\left(\lambda(t-\tau)^{\alpha}\right) .
$$

Further, considering formula (10), represent $I_{2}(t)$ in the form

$$
I_{2}(t)=\int_{0}^{t}(t-\tau)^{\alpha-1} E_{\alpha, \alpha}\left(\lambda(t-\tau)^{\alpha}\right) f(\tau) d \tau .
$$

We obtain formula (7) from (9), (12), and (13). The uniqueness of the solution to the problem follows from the method for constructing the solution, and its smoothness follows from the representation of the solution (7), as well as from the results of [5]. Lemma 1 is proved. 
3. The existence, uniqueness and stability of a solution to Problem A.

To solve the problem, we will apply the spectral method. We will look for a solution to Problem A in the form of $u(x, t)=X(x) \cdot T(t)$. Substituting this expression into equation (1) and boundary conditions (3), we obtain the following spectral problem:

$$
X^{I V}(x)-\lambda^{4} X(x)=0, X(0)=X(1)=X^{\prime \prime}(0)=X^{\prime \prime}(1)=0 .
$$

The problem under consideration is self-adjoint, has a complete system of eigenfunctions in $L_{2}(0,1)$ of the form

$$
X_{n}(x)=\sqrt{2} \sin \lambda_{n} x
$$

which forms a basis in $L_{2}(0,1)$. Here $\lambda_{n}=\pi n, n \in N$.

\subsection{Uniqueness of the solution to problem $A$.}

Let $u(x, t)$ be a solution to Problem A. Consider the following functions:

$$
\begin{aligned}
& u_{n}^{+}(t)=\sqrt{2} \int_{0}^{1} u(x, t) \sin \lambda_{n} x d x, n=1,2, \ldots \\
& u_{n}^{-}(t)=\sqrt{2} \int_{0}^{1} u(x, t) \sin \lambda_{n} x d x, n=1,2, \ldots
\end{aligned}
$$

Applying the operator $D^{\alpha, \gamma}$ to both sides of equality (15) with respect to $t$ at $t \in(0 ; b)$ and differentiating equality (16), with respect to $t$ twice at $t \in(-a ; 0)$, and also taking into account equation (1), we obtain

$$
\begin{aligned}
D^{\alpha, \gamma} u_{n}^{+}(t) & =\sqrt{2} \int_{0}^{1} D^{\alpha, \gamma} u(x, t) \sin \lambda_{n} x d x=-\sqrt{2} \int_{0}^{1} u_{x x x x}(x, t) \sin \lambda_{n} x d x, \\
\frac{d^{2} u_{n}^{-}(t)}{d t^{2}} & =\sqrt{2} \int_{0}^{1} u_{t t}(x, t) \sin \lambda_{n} x d x=-\sqrt{2} \int_{0}^{1} u_{x x x x}(x, t) \sin \lambda_{n} x d x .
\end{aligned}
$$

In the integrals from the right-hand sides of equalities (17) and (18), integrating by parts four times, taking into account boundary conditions (2), we obtain the differential equations

$$
\begin{gathered}
D^{\alpha, \gamma} u_{n}^{+}(t)+\lambda_{n}^{4} u_{n}^{+}(t)=0, t>0, \\
\frac{d^{2}}{d t^{2}} u_{n}^{-}(t)+\lambda_{n}^{4} u_{n}^{-}(t)=0, t<0,
\end{gathered}
$$

the general solutions of which have the form

$$
u_{n}^{ \pm}(t)=\left\{\begin{array}{c}
A_{n} t^{\gamma-1} E_{\alpha, \gamma}\left(-\lambda_{n}^{4} t^{\alpha}\right), t>0, \\
B_{n} \sin \lambda_{n}^{2} t+L_{n} \cos \lambda_{n}^{2} t, t<0,
\end{array}\right.
$$

where $A_{n}, B_{n}, L_{n}, n=1,2, \ldots$ are arbitrary constants.

Taking into account conditions (4) and (5), we obtain from (15), (16) that functions $u_{n}^{ \pm}(t)$ must satisfy the following conditions:

$$
\begin{gathered}
\lim _{t \rightarrow+0} J_{0+}^{1-\gamma} u_{n}^{+}(t)=\lim _{t \rightarrow-0} u_{n}^{-}(t), \lim _{t \rightarrow+0} J_{0+}^{1-\alpha}\left(\frac{d}{d t} J_{0+}^{1-\gamma} u_{n}^{+}(t)\right)=\lim _{t \rightarrow-0} \frac{d u_{n}^{-}(t)}{d t}, \\
\frac{d u_{n}^{-}(-a)}{d t}=D^{\alpha, \gamma} u_{n}^{+}(b)+\varphi_{n}
\end{gathered}
$$


where

$$
\varphi_{n}=\sqrt{2} \int_{0}^{1} \varphi(x) \sin \lambda_{n} x d x, n=1,2, \ldots
$$

Further, satisfying functions (21) and conditions (22)-(23), we obtain the following system for finding the constants $A_{n}, B_{n}, L_{n}$ :

$$
\left\{\begin{array}{c}
A_{n}=L_{n}, B_{n}=-\lambda_{n}^{2} A_{n}, \\
L_{n} \lambda_{n}^{2} \sin \lambda_{n}^{2} a+B_{n} \lambda_{n}^{2} \cos \lambda_{n}^{2} a+\lambda_{n}^{4} A_{n} b^{\gamma-1} E_{\alpha, \gamma}\left(-\lambda_{n}^{4} b^{\alpha}\right)=\varphi_{n} .
\end{array}\right.
$$

The system, having the unique solution of the form

$$
L_{n}=A_{n}, B_{n}=-\lambda_{n}^{2} A_{n}, A_{n}=\frac{\varphi_{n}}{\lambda_{n}^{2} \Delta_{n}(a, b)},
$$

provided that for all $n \in N$ the equality

$$
\Delta_{n}(a, b) \neq 0, \Delta_{n}(a, b)=\sin \lambda_{n}^{2} a-\lambda_{n}^{2} \cos \lambda_{n}^{2} a+\lambda_{n}^{2} b^{\gamma-1} E_{\alpha, \gamma}\left(-\lambda_{n}^{4} b^{\alpha}\right)
$$

holds.

Substituting (25) into (21), we finally obtain

$$
u_{n}^{ \pm}(t)=\left\{\begin{array}{c}
\frac{\varphi_{n}}{\lambda_{n}^{2} \Delta_{n}(a, b)} t^{\gamma-1} E_{\alpha, \gamma}\left(-\lambda_{n}^{4} t^{\alpha}\right), t>0 \\
\frac{\varphi_{n}}{\lambda_{n}^{2} \Delta_{n}(a, b)}\left(\cos \lambda_{n}^{2} t-\lambda_{n}^{2} \sin \lambda_{n}^{2} t\right), t \leq 0 .
\end{array}\right.
$$

Using (27), it is easy to prove the uniqueness of the solution to Problem A. Indeed, let condition (26) be satisfied and $\varphi(x) \equiv 0$. Then $\varphi_{n}=0$, and formulas (15), (16), and (27) imply

$$
\begin{gathered}
\int_{0}^{1} t^{1-\gamma} u(x, t) \sin \lambda_{n} x d x=0, t \in[0, b], n=1,2, \ldots, \\
\int_{0}^{1} u(x, t) \sin \lambda_{n} x d x=0, t \in[-a, 0], n=1,2, \ldots
\end{gathered}
$$

Further, taking into account the completeness of system (14) in $L_{2}(0,1)$, we conclude that $u(x, t)=0$ almost everywhere on $[0,1]$ at any $t \in[-a, b]$. Since $t^{1-\gamma} u(x, t) \in C\left(\bar{\Omega}_{1}\right), u(x, t) \in C\left(\bar{\Omega}_{2}\right)$, we have $t^{1-\gamma} u(x, t) \equiv 0$ in $\bar{\Omega}$, that is, problem A has the unique solution in the class under consideration.

Thus, the following statement holds.

Theorem 1. If there exists a solution to Problem A, then, it is unique if and only if conditions (26) are satisfied for all $n \in N$.

Now let us consider the case when condition (26) is violated. Let $\Delta_{m}(a, b)=0$ for some $a, b, \gamma \in(0,1]$, and $n=m$. Then the homogeneous Problem A (where $\varphi(x) \equiv 0$ ) has the nontrivial solution

$$
\begin{gathered}
V_{m}^{ \pm}(x, t)=\sqrt{2} v_{m}^{ \pm}(t) \sin \lambda_{m} x, \\
v_{m}^{ \pm}(t)=\left\{\begin{array}{c}
t^{\gamma-1} E_{\alpha, \gamma}\left(-\lambda_{m}^{4} t^{\alpha}\right), t>0, \\
\cos \lambda_{m}^{2} t-\lambda_{m}^{2} \sin \lambda_{m}^{2} t, t<0 .
\end{array}\right.
\end{gathered}
$$

Now, represent the expression $\Delta_{n}(a, b)$ in the form:

$$
\Delta_{n}(a, b)=\sqrt{1+\lambda_{n}^{4}} \sin \left(\lambda_{n}^{2} a-\rho_{n}\right)+\lambda_{n}^{2} b^{\gamma-1} E_{\alpha, \gamma}\left(-\lambda_{n}^{4} b^{\alpha}\right),
$$


where $\rho_{n}=\arcsin \left(\lambda_{n}^{2} / \sqrt{1+\lambda_{n}^{4}}\right)$ and $\rho_{n} \rightarrow \frac{\pi}{2}$ at $n \rightarrow+\infty$. From this, it can be seen that the expression $\Delta_{n}(a, b)$ vanishes only if

$$
a=\frac{1}{\lambda_{n}^{2}}\left[(-1)^{k+1} \arcsin \frac{\lambda_{n}^{2} b^{\gamma-1} E_{\alpha, \gamma}\left(-\lambda_{n}^{4} b^{\alpha}\right)}{\sqrt{1+\lambda_{n}^{4}}}+\pi k+\rho_{n}\right], n=1,2, \ldots
$$

Since $\Delta_{n}(a, b)$ is the denominator of the fraction, for sufficiently large $\mathrm{n}$, the expression $\Delta_{n}(a, b)$ can become sufficiently small, i.e., the problem of "small denominators" has arisen. Therefore, to substantiate the existence of a solution to this problem, it is necessary to show the existence of numbers $a$ and $b$ such that, for sufficiently large $\mathrm{n}, \Delta_{n}(a, b)$ will be separated from zero.

Lemma 2. Let $\gamma \in(0,1], b$ be any positive real number, $a$ be an irrational number such that either $a \pi \in N$ or $\pi a=\frac{p}{q} \in Q \backslash N$ where $p, q \in N,(p, q)=1$ and $q$ is an odd number. Then for large $n$ there exists a positive constant $B_{0}$ such that the estimate

$$
\left|\Delta_{n}(a, b)\right| \geq B_{0} n^{2}>0
$$

is valid.

Proof. Let $\pi a=p \Leftrightarrow a=\frac{p}{\pi}, p \in N$. Then, we have from (26)

$$
\left|\Delta_{n}(a, b)\right|=\lambda_{n}^{2}\left|(-1)^{a+1}+b^{\gamma-1} E_{\alpha, \gamma}\left(-\lambda_{n}^{4} b^{\alpha}\right)\right| \geq \lambda_{n}^{2}\left(1-b^{\gamma-1} E_{\alpha, \gamma}\left(-\lambda_{n}^{4} b^{\alpha}\right)\right)
$$

at all $n$ and $b>0$.

Here and below, we use the following properties of the Mittag-Leffler function:

1. For $\alpha, \beta \in(0,1], \alpha \leq \beta$, the function $E_{\alpha, \beta}(-z)$ is completely monotone on $(0, \infty)[1$, Vol 1, p. 280$]$.

2. Let $\alpha \in(0,2), \beta$ be a real constant, and $\arg z=\pi$. Then the inequality

$$
\left|E_{\alpha, \beta}(z)\right| \leq \frac{M}{1+|z|}
$$

takes place, where $M$ is a positive constant independent of $z[22 ; 136]$.

Then, it follows from (29) that there exists $n_{0} \in N$ such that for all $n>n_{0}$ the inequality

$$
\lambda_{n}^{2}\left(1-b^{\gamma-1} E_{\alpha, \gamma}\left(-\lambda_{n}^{4} b^{\alpha}\right)\right) \geq B_{1} n^{2}>0
$$

holds and hence $\Delta_{n}(a, b) \geq B_{1} n^{2}>0$.

Let now $a=\frac{p}{q \pi}, p, q \in N,(q, p)=1, q$ be an odd number. Divide $n^{2} p$ by $q$ with a remainder: $n^{2} p=s q+r$ where $s, r, \in N \cup\{0\}, 0 \leq r<q$. Then expression (29) takes the form

$$
\Delta_{n}(a, b)=\sqrt{1+\lambda_{n}^{4}}(-1)^{s+1} \cos \left(\frac{\pi r}{q}+\varepsilon_{n}\right)+\lambda_{n}^{2} b^{\gamma-1} E_{\alpha, \gamma}\left(-\lambda_{n}^{4} b^{\alpha}\right)
$$

where $\varepsilon_{n}=\arcsin \left(1 / \sqrt{1+\lambda_{n}^{4}}\right)>0$ and $\varepsilon_{n} \rightarrow 0$ at $n \rightarrow+\infty$.

Let $r=0$. Then we have the case considered above. Let $r>0$. Then $1 \leq r \leq q-1, q \geq 2$, and for large $n$ $0<\frac{\pi}{q}+\varepsilon_{n} \leq \frac{\pi r}{q}+\varepsilon_{n} \leq \pi-\frac{\pi}{q}+\varepsilon_{n}<\pi$.

Hence, it follows that if $\stackrel{q}{q}=2 l, l \in N$, then for $r=l$, we obtain that $\frac{\pi r}{q}+\varepsilon_{n} \rightarrow \frac{\pi}{2}$ at $n \rightarrow+\infty$, and if $q=2 l+1$, then $\frac{\pi r}{q} \neq \frac{\pi}{2}$ at any $r$ from $[1, q-1]$. Since $\varepsilon_{n} \rightarrow 0$ and $b^{\gamma-1} E_{\alpha, \gamma}\left(-\lambda_{n}^{4} b^{\alpha}\right) \rightarrow 0$ at $n \rightarrow+\infty$, there exists a constant $n_{1}>0$ such that

$$
\left|\cos \left(\frac{\pi r}{q}+\varepsilon_{n}\right)\right|-b^{\gamma-1} E_{\alpha, \gamma}\left(-\lambda_{n}^{4} b^{\alpha}\right) \geq \frac{1}{2}\left|\cos \frac{\pi r}{q}\right|-b^{\gamma-1} E_{\alpha, \gamma}\left(-\lambda_{n}^{4} b^{\alpha}\right) \geq B_{2},
$$

where $0<B_{2}<\frac{1}{2}\left|\cos \frac{\pi r}{q}\right|$. Then, taking into account these estimates, we obtain from (33) for $n>n_{1}$ :

$$
\begin{gathered}
\left|\Delta_{a, b}\right| \geq \lambda_{n}^{2}\left(\cos \left(\frac{\pi r}{q}+\varepsilon_{n}\right)-b^{\gamma-1} E_{\alpha, \gamma}\left(-\lambda_{n}^{4} b^{\alpha}\right)\right) \geq \\
\geq \lambda_{n}^{2}\left(\frac{1}{2}\left|\cos \frac{\pi r}{q}\right|-b^{\gamma-1} E_{\alpha, \gamma}\left(-\lambda_{n}^{4} b^{\alpha}\right)\right) \geq \pi^{2} B_{2} n^{2} .
\end{gathered}
$$


It follows from (32) and (34) that (30) is valid for large $n$.

Lemma 2 is proved.

Note that the idea of the proof of Lemma 2 was borrowed from [18].

\subsection{The existence of a solution to Problem A.}

Let us turn to the proof of the existence of a solution to Problem A. The proof of the following lemma follows easily from (26), (30) and estimate (31).

Lemma 3. Let conditions (26) and (30) be satisfied. Then

1) if $t \in[0, b]$, then

$$
t^{1-\gamma}\left|u_{n}^{+}(t)\right| \leq \frac{B_{3}}{n^{4}}\left|\varphi_{n}\right|, t^{1-\gamma}\left|D^{\alpha, \gamma} u_{n}^{+}(t)\right| \leq B_{4}\left|\varphi_{n}\right|
$$

2) if $t \in[-a, 0]$, then

$$
\left|u_{n}^{-}(t)\right| \leq \frac{B_{5}}{n^{2}}\left|\varphi_{n}\right|,\left|\frac{d u_{n}^{-}(t)}{d t}\right| \leq B_{6}\left|\varphi_{n}\right|,\left|\frac{d^{2} u_{n}^{-}(t)}{d t^{2}}\right| \leq B_{7} n^{2}\left|\varphi_{n}\right|,
$$

here and below $B_{k}, k=\overline{1,7}$ are positive constants. Since system (14) is complete and forms a basis in $L_{2}(0,1)$, we look for a solution to Problem $\mathrm{A}$ in $\Omega$ in the form

$$
u(x, t)=\left\{\begin{array}{l}
\sqrt{2} \sum_{n=1}^{\infty} u_{n}^{+}(t) \sin \lambda_{n} x, \quad(x, t) \in \Omega_{1}, \\
\sqrt{2} \sum_{n=1}^{\infty} u_{n}^{-}(t) \sin \lambda_{n} x, \quad(x, t) \in \Omega_{2},
\end{array}\right.
$$

where $u_{n}^{ \pm}(t)$ are unknown functions. It is not difficult to see that, substituting function (35) into (1) and satisfying conditions (3)-(5) with respect to the sought functions, we obtain problem (19), (20), (22), (23), the solution of which has the form (27).

Thus, the solution to the problem can be represented in the form (35), where $u_{n}^{ \pm}(t)$ are determined by formulas (27). Now, it remains to prove the legality of all these actions. For this, we formally compose the series from (35), using term-by-term differentiation

$$
\begin{gathered}
D^{\alpha, \gamma} u(x, t)=\sum_{n=1}^{\infty} D^{\alpha, \gamma} u_{n}^{+}(t) X_{n}(x), t>0, \\
\frac{\partial^{k} u(x, t)}{\partial x^{k}}=\sum_{n=1}^{\infty} u_{n}^{+}(t) \frac{d^{k} X_{n}(x)}{d x^{k}}, k=\overline{1,4}, t>0, \\
\frac{\partial^{2} u(x, t)}{\partial t^{2}}=\sum_{n=1}^{\infty} \frac{d^{2} u_{n}^{-}(t)}{d t^{2}} X_{n}(x), t<0, \\
\frac{\partial^{k} u(x, t)}{\partial x^{k}}=\sum_{n=1}^{\infty} u_{n}^{-}(t) \frac{d^{k} X_{n}(x)}{d x^{k}}, k=\overline{1,4}, t<0 .
\end{gathered}
$$

Taking into account Lemmas 2, 3 one can easily see that series (38), (39), and series

$$
\sum_{n=1}^{\infty} t^{1-\gamma} D^{\alpha, \gamma} u_{n}^{+}(t) X_{n}(x), \sum_{n=1}^{\infty} t^{1-\gamma} u_{n}^{+}(t) \frac{d^{k} X_{n}(x)}{d x^{k}}, k=\overline{0,4} t>0
$$

which are obtained from (36) and (37) by term-by-term multiplication by , are majorized by the series

$$
\sum_{n=1}^{\infty} n^{2}\left|\varphi_{n}\right|
$$


Therefore, we investigate the convergence of series (41). Taking into account the relation

$$
\varphi_{n}=\frac{1}{(\pi n)^{3}} \varphi_{n}^{(3)}=-\frac{\sqrt{2}}{(\pi n)^{3}} \int_{0}^{1} \varphi^{\prime \prime \prime}(x) \cos \lambda_{n} x d x,
$$

as well as using the Cauchy-Schwarz and Bessel inequality, we have

$$
\sum_{n=1}^{\infty} n^{2}\left|\varphi_{n}\right| \leq \sum_{n=1}^{\infty} \frac{1}{n}\left|\varphi_{n}^{(3)}\right| \leq\left(\sum_{n=1}^{\infty} \frac{1}{n^{2}}\right)^{1 / 2} \cdot\left(\sum_{n=1}^{\infty}\left|\varphi_{n}^{(3)}\right|^{2}\right)^{1 / 2} \leq C\left\|\varphi^{(3)}(x)\right\|_{L_{2}(0,1)},
$$

where $\sum_{n=1}^{\infty} \frac{1}{n^{2}}=\frac{\pi^{2}}{6}$. Then, by the Weierstrass theorem, series (38)-(40) converge absolutely and uniformly in domains $\bar{\Omega}_{1}$ and $\bar{\Omega}_{2}$, respectively.

There fore it follows that the function $u(x, t)$, defined by series (36), belongs to class (2), and also satisfies the conditions $(3)-(5)$.

Now, let $\Delta_{n}(a, b)=0$ at some and $n=k_{1}, \ldots, k_{s}, 1 \leq k_{1}<k_{1}<\ldots<k_{s}, s \in N$.. Then the fulfillment of the orthogonality conditions is necessary and sufficient for the solvability of system (24)

$$
\varphi_{n}=\sqrt{2} \int_{0}^{1} \varphi(x) \sin \lambda_{n} x d x=0, n=k_{1}, \ldots k_{s} .
$$

In this case, the solution to Problem is defined as the sum of the series

$$
u(x, t)=\sqrt{2}\left[\sum_{n=1}^{k_{1}-1}+\sum_{n=k_{1}+1}^{k_{2}-1}+\ldots+\sum_{n=k_{s}+1}^{\infty}+\right] u_{n}^{ \pm}(t) \sin \lambda_{n} x+\sum_{m} C_{m} V_{m}^{ \pm}(t),
$$

where in the last sum $m=k_{1}, \ldots k_{s}, C_{m}$ are arbitrary constants, functions $V_{m}^{ \pm}(t)$ are determined from formula (28).

Thus, the following statement holds.

Theorem 2. Let $\varphi(x) \in C^{2}[0,1], \varphi^{(3)}(x) \in L_{2}(0,1), \varphi^{(2 k)}(0)=\varphi^{(2 k)}(1)=0, k=\overline{0,1}$. Then Problem A is uniquely solvable if only if conditions (26) and (30) hold, and the solution is determined by series (35). If $\Delta_{n}(a, b)=0$ for some $a, b, \gamma$, and $n=k_{1}, \ldots, k_{s}$, moreover condition (30) takes place, then Problem A is solvable only if orthogonality conditions (42) take place. In this case, the solution is determined by series (43).

\subsection{Stability of the solution to Problem A.}

Now, let us establish the stability of the solution to problem A with respect to its nonlocal condition (4). Let

$$
\begin{aligned}
\|u(x, t)\|_{C(\bar{\Omega})} & =\left\|t^{1-\gamma} u(x, t)\right\|_{C\left(\bar{\Omega}_{1}\right)}+\|u(x, t)\|_{C\left(\bar{\Omega}_{2}\right)}, \\
\|u(x, t)\|_{L_{2}(\Omega)} & =\left\|t^{1-\gamma} u(x, t)\right\|_{L_{2}\left(\Omega_{1}\right)}+\|u(x, t)\|_{L_{2}\left(\Omega_{2}\right)},
\end{aligned}
$$

where

$$
\begin{gathered}
\|v(x, t)\|_{C(\bar{\Omega})}=\max _{\bar{\Omega}}|v(x, t)|, \\
\|f(x)\|_{C[0,1]}=\max _{[0,1]}|f(x)|, \\
\|v(x, t)\|_{L_{2}(\Omega)}=\left(\iint_{\Omega}|v(x, t)|^{2} d x d t\right)^{1 / 2},\|\varphi(x)\|_{L_{2}(0,1)}=\left(\int_{0}^{1}|\varphi(x)|^{2} d x\right)^{1 / 2} .
\end{gathered}
$$

Theorem 3. Let the conditions of Theorem 2 be satisfied. Then the solution to Problem A satisfies the estimate

$$
\|u(x, t)\|_{C(\bar{\Omega})} \leq C\|\varphi(x)\|_{C[0,1]},
$$




$$
\|u(x, t)\|_{L_{2}(\Omega)} \leq C\|\varphi(x)\|_{L_{2}(0,1)} .
$$

In what follows, $C$ will mean an arbitrary constant, the value of which is not of interest to us.

Proof. Let $(x, t)$ be an arbitrary point from the domain $\bar{\Omega}_{2}$. Then using formulas $(27),(35)$, on the base of Lemma 3 and the Cauchy-Bunyakovsky inequality, we obtain the estimate:

$$
|u(x, t)| \leq \sqrt{2} \sum_{n=1}^{\infty}\left|u_{n}^{-}(t)\right| \leq \sqrt{2} B_{5} \sum_{n=1}^{\infty} \frac{1}{n^{2}}\left|\varphi_{n}\right|,
$$

it easily follows from this that

$$
\|u(x, t)\|_{C\left(\bar{\Omega}_{2}\right)} \leq C\|\varphi(x)\|_{C[0,1]} .
$$

In the same way, in the case of $(x, t) \in \bar{\Omega}_{1}$, we obtain the estimate

$$
\left\|t^{1-\gamma} u(x, t)\right\|_{C\left(\bar{\Omega}_{1}\right)} \leq C\|\varphi(x)\|_{C[0,1]} .
$$

Estimate (44) follows from (46) and (47). Now we prove estimate (45). Since system (14) is orthonormal in $L_{2}(0,1)$, we get from $(35)$, using the Parseval equality,

$$
\|u(x, t)\|_{L_{2}\left(\Omega_{2}\right)}^{2}=\left(\sum_{n=1}^{\infty} u_{n}(t) X_{n}(x), \sum_{m=1}^{\infty} u_{m}(t) X_{m}(x)\right)_{L_{2}\left(\Omega_{2}\right)}=\sum_{n=1}^{\infty}\left\|u_{n}(t)\right\|_{L_{2}(-a, 0)}^{2} .
$$

Hence, based on Lemma 3, we get

$$
\|u(x, t)\|_{L_{2}\left(\Omega_{2}\right)} \leq C\|\varphi(x)\|_{L_{2}(0,1)} .
$$

In a similar way we obtain the estimate

$$
\left\|t^{1-\gamma} u(x, t)\right\|_{L_{2}\left(\Omega_{1}\right)} \leq C\|\varphi(x)\|_{L_{2}(0,1)} .
$$
$\varphi(x)$.

Estimate (45) follows from (48) and (49). Therefore, solution (35) continuously depends on the function

Theorem 3 is proved.

\section{Some examples}

Example 1. Consider Problem A at $\gamma=1$. Then $D^{\alpha, \gamma}=D^{\alpha, 1}={ }_{C} D^{\alpha}$ and equation (1) has the form

$$
0=\left\{\begin{array}{l}
\frac{\partial^{4} u}{\partial x^{4}}+{ }_{C} D^{\alpha} u, t>0 \\
\frac{\partial^{4} u}{\partial x^{4}}+\frac{\partial^{2} u}{\partial t^{2}}, t<0
\end{array}\right.
$$

we obtain Problem A for equation (50) with the Caputo operator ${ }_{C} D^{\alpha}$, the solution of which has the form

$$
u(x, t)=\left\{\begin{array}{c}
\sum_{n=1}^{\infty} \frac{\sqrt{2} \varphi_{n}}{\lambda_{n}^{2} \Delta_{n}(a, b)} E_{\alpha, 1}\left(-\lambda_{n}^{4} t^{\alpha}\right) \sin \lambda_{n} x, \quad(x, t) \in \Omega_{1}, \\
\sum_{n=1}^{\infty} \frac{\sqrt{2} \varphi_{n}}{\lambda_{n}^{2} \Delta_{n}(a, b)}\left(\cos \lambda_{n}^{2} t-\lambda_{n}^{2} \sin \lambda_{n}^{2} t\right) \sin \lambda_{n} x, \quad(x, t) \in \Omega_{2} .
\end{array}\right.
$$

Example 2. Consider the case of $\gamma=\alpha=1$. Then $D^{\alpha, \gamma}=D^{1,1}=\frac{d}{d t}$ and equation (1) has the form

$$
0=\left\{\begin{array}{l}
\frac{\partial^{4} u}{\partial x^{4}}+\frac{\partial u}{\partial t}, t>0 \\
\frac{\partial^{4} u}{\partial x^{4}}+\frac{\partial^{2} u}{\partial t^{2}}, t<0
\end{array}\right.
$$


we obtain the integer partial differential equation. Since $E_{1,1}(z)=e^{z}$, the solution of the obtained problem has the form

$$
u(x, t)=\left\{\begin{array}{c}
\sum_{n=1}^{\infty} \frac{\sqrt{2} \varphi_{n}}{\lambda_{n}^{2} \Delta_{n}(a, b)} e^{-\lambda_{n}^{4} t^{\alpha}} \sin \lambda_{n} x, \quad(x, t) \in \Omega_{1}, \\
\sum_{n=1}^{\infty} \frac{\sqrt{2} \varphi_{n}}{\lambda_{n}^{2} \Delta_{n}(a, b)}\left(\cos \lambda_{n}^{2} t-\lambda_{n}^{2} \sin \lambda_{n}^{2} t\right) \sin \lambda_{n} x, \quad(x, t) \in \Omega_{2} .
\end{array}\right.
$$

\section{Conclusion}

In the paper, we established a criterion for the existence and uniqueness of a regular solution to a nonlocal problem for a fourth-order mixed-type differential equation with the Hilfer operator in a rectangular domain. For this, we used the spectral method, which allowed to construct a solution to the nonlocal problem (1)-(5) in the form of a Fourier series. Next, we proveed the stability of the obtained solution with respect to the problem data. Moreover, we provided a simple way to solve the Cauchy problem for a fractional differential equation with a generalized Riemann - Liouville derivative.

\section{References}

1 Handbook of Fractional Calculus with Applications in 8 volumes (edited by J.A. Tenreiro Machado). Berlin-Boston: Walter de Gruyter GmbH, 2019.

2 Hilfer R. (ed.) Applications of Fractional Calculus in Physics / R. Hilfer (ed.) // World Scientific Publishing Company, Singapore, New Jersey, London and Hong Kong, 2000.

3 Sandev T. Fractional diffusion equation with a generalized Riemann-Liouville time fractional derivative / T. Sandev, R. Metzler, Z. Tomovski // Journal of Physics A: Mathematical and Theoretical. - 2011. 44. - No. 25. - P. 21. - 255203.

4 Tomovski Z. Generalized space-time fractional diffusion equation with composite fractional time derivative / Z Tomovski, T. Sandev, R. Metzler, J. Dubbeldam // Physica A. - 2012. - 391. - No. 8. - P. 2527-2542.

5 Hilfer R. Operational method for the solution of fractional differential equations with generalized RiemannLiouville fractional derivatives / R.Hilfer, Y. Luchko, Z. Tomovski // Fractional calculus and applied analysis. $-2009 .-12 .-$ No. 3. - P. 299-318.

6 Myong-Ha Kim. Operational method for solving multi-term fractional differential equations with the generalized fractional derivatives / Kim Myong-Ha, Ri Guk-Chol, O. Hyong-Chol // Fract. Calc. Appl. Anal. - 2014. - 17. - No. 1. - P. 79-95. -DOI: 10.2478/s13540-014-0156-6.

7 Malik S.A. An inverse source problem for a two parameter anomalous diffusion equation with nonlocal boundary conditions / S.A. Malik, S. Aziz // Computers and Mathematics with Applications. - 2017. http://dx.doi.org/10.1016/j.camwa.2017.03.019.

8 Aziz S. Identification of an unknown source term for a time fractional fourth-order parabolic equation / S. Aziz, Salman A. Malik // Electronic Journal of Differential Equations. - 2016. - No. 293. - P. 1-20. ISSN: 1072-6691.

9 Sun H. A review on variable-order fractional differential equations: mathematical foundations, physical models, numerical methods and applications / H. Sun, A. Chang, Y. Zhang, W. Chen // Fract. Calc. Appl. Anal. - 2019. - 22. - P. 27-59. DOI:10.1515/fca-2019-0003.

10 Kumar D. Fractional Calculus and Its Applications in Physics / D. Kumar, D. Baleanu // Front. Phys. - 2019. https://doi.org/10.3389/fphy.2019.00081.

11 Ram K. Analytical solution of space-time fractional telegraph-type equations involving Hilfer and Hadamard derivatives / K.Ram, Saxena, Roberto Garra, Enzo Orsingher // Integral Transforms and Special Functions. - 2015. - 27. - No. 1. - P. 30-42. DOI: 10.1080/10652469.2015.1092142.

12 Patnaik S. Applications of variable-order fractional operators: a review / S. Patnaik, J.P. Hollkamp, F. Semperlotti // Proc. R. Soc. A476: 20190498. - 2020. http://dx.doi.org/10.1098/rspa.2019.0498.

13 Sandev T. Fractional Equations and Models: Theory and Applications / T. Sandev, Z. Tomovski. Springer, 2019. https://doi.org/10.1007/978-3-030-29614-8. 
14 Нахушев А.М. Задачи со смещением для уравнений в частных производных / А.M. Нахушев. - М.: Наука, 2006. - 287 с.

15 Sabitov K.B. Nonlocal Problem for a Parabolic-Hyperbolic Equation in a Rectangular Domain / K.B. Sabitov // Mathematical Notes. - 2011. - 89. - No. 4. - P. 562-567.

16 Sabitov K. B. Inverse Problem for an Equation of Parabolic-Hyperbolic Type with a Nonlocal Boundary Condition / K.B. Sabitov, G.R. Yunusova // Differential Equations. - 2012. - 48. - No. 2. - P. $246-254$.

17 Сабитов К.Б. Обратная задача для вырождающегося параболо-гиперболического уравнения с нелокальным граничным условием / К.Б.Сабитов, С.Н.Сидоров // Изв. вузов. Математика. - 2015. № 1. - C. 46-59.

18 Юнусова Г.Р. Нелокальные задачи для уравнения смешанного параболо-гиперболического типа / Г.Р. Юнусова // Вестн. СамГУ. Ест.-науч. сер. - 2011. - 8. - № 89. - С. 108-117.

19 Yuldashev T. K. Boundary value problem for weak nonlinear partial differential equations of mixed type with fractional Hilfer operator / T.K. Yuldashev, B.J. Kadirkulov // Axioms. - 2020. - 9. - No. 2. P. 1-19. https://doi.org/10.3390/axioms9020068.

20 Yuldashev T.K. Nonlocal problem for a mixed type fourth-order differential equation with Hilfer fractional operator / T.K. Yuldashev, B.J. Kadirkulov // Ural Math. - 2020. - 6. - No 1. - P. 153-167. http://dx.doi. org/10.15826/umj.2020.1.013.

21 Berdyshev A.S. Boundary value problems for fourth-order mixed type equation with fractional derivative / A.S. Berdyshev, J.B. Kadirkulov, B.E. Eshmatov // Electronic Journal of Differential Equations. 2016. - 2016. - No. 36. - P. 1-11.

22 Джрбашян М.М. Интегральные преобразования и представления функций в комплексной области / M.M. Джрбашян. - М.: Наука, 1966. - 672 с.

23 Kilbas A. A. Theory and applications of fractional differential equations / A.A. Kilbas, H.M. Srivastava, J.J. Trujillo // North-Holland Mathematics Studies, 204. Elsevier Science B. V., Amsterdam, 2006. XVI. - P. 523 .

\author{
Б.Ж. Кадиркулов ${ }^{1}$, М.А. Жалилов ${ }^{2}$ \\ ${ }^{1}$ Ташкент мемлекеттік шыъыстану университеті, Ташкент, Өзбекстан; \\ ${ }^{2}$ Фергана мемлекеттік университеті, Фергана, Өзбекстан
}

\title{
Төртінші ретті аралас типті теңдеу үшін бір бейлокалды есеп жайында
}

\begin{abstract}
Мақалада Риман-Лиувиллдің жалпыланған операторымен аралас төртінші ретті теңдеу үшін интегродифференциалды түйіндес шартты бір бейлокалды есептің шешілу мәселелерін зерттеуге арналған. Белгілі бір шарттарда берілген параметрлер мен функциялар үшін қойылған есептің шешімінің жалғыз және бар болу теоремалары дәлелденді. Бұл шарттар бұзылған кезде қойылған есептің нөлдік емес шешімі бар болатыны жайында мысал келтірілген. Есептің шешімінің жалғыз және бар болу теоремаларын дәлелдеу үшін айнымалыларды бөлу әдісі қолданылды. Шешімнің өзі бірөлшемді спектрлік есепке сәйкес абсолютті және бірқалыпты жинақталатын қатар түрінде алынған. Коши есебі жалпыланған интегро-дифференциалдау операторы бар бөлшек теңдеу үшін зерттелді, осы есепті эквивалентті интегралды теңдеудің шешімділігі мағынасында шешімін табудың қарапайым әдісі көрсетілген. Бейлокалды шарт бойынша қарастырылған есептің тұрақтылығы алынған.
\end{abstract}

Kiлm сөздер: аралас типті теңдеу, бейлокалды шеттік есеп, шешімнің бар және жалғыз болуы, бөлшекті интегро-дифференциалдау операторы, Хилфер операторы, Миттаг-Леффлер функциясы. 


\author{
Б.Ж. Кадиркулов ${ }^{1}$, М.А. Жалиилов ${ }^{2}$ \\ ${ }^{1}$ Ташкентский государственный университет востоковедения, Ташкент, Узбекистан; \\ ${ }^{2}$ Ферганский государственный университет, Фергана, Узбекистан
}

\title{
Об одной нелокальной задаче для уравнения смешанного типа четвертого порядка с оператором Хилфера
}

\begin{abstract}
Статья посвящена исследованию вопросов разрешимости одной нелокальной задачи с интегродифференциальным условием сопряжения для уравнения смешанного типа четвертого порядка с обобщенным оператором Римана-Лиувилля. При определенных условиях на заданные параметры и функции доказаны теоремы единственности и существования решения поставленной задачи. Приведен пример, показывающий, что при нарушении этих условий, сформулированная задача будет иметь нетривиальное решение. Для доказательства теорем единственности и существования решения поставленной задачи использован метод разделения переменных. Само решение построено в виде суммы абсолютно и равномерно сходящегося ряда по собственным функциям соответствующей одномерной спектральной задачи. Изучена задача Коши для дробного уравнения с обобщенным оператором интегро-дифференцирования, показан простой способ нахождения решения этой задачи путем сведения её к эквивалентному в смысле разрешимости интегральному уравнению. Авторами также установлена устойчивость решения рассматриваемой задачи по нелокальному условию.
\end{abstract}

Ключевые слова: уравнение смешанного типа, нелокальная краевая задача, существование и единственность решения, оператор дробного интегро-дифференцирования, оператор Хилфера, функция Миттаг-Леффлера.

\section{References}

1 Tenreiro Machado, J.A. (2019). Handbook of Fractional Calculus with Applications in 8 volumes. BerlinBoston: Walter de Gruyter GmbH.

2 Hilfer, R. (2000). Applications of Fractional Calculus in Physics. World Scientific Publishing Company, Singapore, New Jersey, London and Hong Kong.

3 Sandev, T., Metzler, R., \& Tomovski, Z. (2011). Fractional diffusion equation with a generalized RiemannLiouville time fractional derivative. Journal of Physics A: Mathematical and Theoretical 44 (25), 255203.

4 Tomovski, Z., Sandev, T., Metzler, R., \& Dubbeldam, J. (2012). Generalized space-time fractional diffusion equation with composite fractional time derivative. Physica A 391(8), 2527-2542.

5 Hilfer, R., Luchko, Y., \& Tomovski, Z. (2009). Operational method for the solution of fractional differential equations with generalized Riemann-Liouville fractional derivatives. Fractional calculus and applied analysis, 12, 3, 299-318. Retrieved from http://www.math.bas.bg/ fcaa/volume12/fcaa123

6 Kim, M.Ha., Chol, Ri.G., \& Chol, O.H. (2014). Operational method for solving multi-term fractional differential equations with the generalized fractional derivatives. Fract. Calc. Appl. Anal., 17, 1, 79-95. DOI: $10.2478 / \mathrm{s} 13540-014-0156-6$

7 Malik, S.A., \& Aziz, S. (2017). An inverse source problem for a two parameter anomalous diffusion equation with nonlocal boundary conditions, Computers and Mathematics with Applications. Computers and Mathematics with Applications. http://dx.doi.org/10.1016/j.camwa.2017.03.019.

8 Aziz S., \& Malik S.A. (2016). Identification of an unknown source term for a time fractional fourth-order parabolic equation. Electronic Journal of Differential Equations, 2016, 293, 1-20. ISSN: 1072-6691.

9 Sun, H., Chang, A., Zhang, Y., \& Chen, W. (2015). A review on variable-order fractional differential equations: mathematical foundations, physical models, numerical methods and applications. Fract. Calc. Appl. Anal. 22, 27-59. (doi:10.1515/fca-2019-0003).

10 Kumar, D., \& Baleanu, D. (2019). Fractional Calculus and Its Applications in Physics Front. Phys., 2019, https://doi.org/10.3389/fphy.2019.00081.

11 Ram, K. Saxena, Roberto Garra., \& Enzo Orsingher. (2015). Analytical solution of space-time fractional telegraph-type equations involving Hilfer and Hadamard derivatives. Integral Transforms and Special Functions, DOI: 10.1080/10652469.2015.1092142. 
12 Patnaik, S., Hollkamp, J.P., \& Semperlotti, F. (2019). Applications of variable-order fractional operators: a review. Proc. R. Soc. A476: 20190498. http://dx.doi.org/10.1098/rspa.2019.0498.

13 Sandev, T., \& Tomovski, Z. (2019). Fractional Equations and Models: Theory and Applications. Springer. https://doi.org/10.1007/978-3-030-29614-8.

14 Nakhushev, A.M. (2006). Zadachi so smeshcheniem dlia uravnenii v chastnykh proizvodnykh [Problems with Shift for Partial Differential Equations]. Moscow: Nauka [in Russian].

15 Sabitov, K. B. (2011). Nonlocal Problem for a Parabolic-Hyperbolic Equation in a Rectangular Domain. Mathematical Notes, 89, 4, 562-567.

16 Sabitov, K. B., \& Yunusova, G. R. (2012). Inverse Problem for an Equation of Parabolic-Hyperbolic Type with a Nonlocal Boundary Condition. Differential Equations, 48, 2, 246-254.

17 Sabitov, K.B., \& Sidorov, S.N. (2015). Obratnaia zadacha dlia vyrozhdaiushchegosia parabolo-giperbolicheskogo uravneniia s nelokalnym granichnym usloviem [Inverse problem for degenerate parabolichyperbolic equation with nonlocal boundary condition]. Izvestiia vuza. Matematika - Proceedings of universities. Maths., 59:1, 39-50 [in Russian].

18 Yunusova, G.R. (2011). Nelokalnye zadachi dlia uravneniia smeshannogo parabolo-giperbolicheskogo tipa [Nonlocal problems for the equation of the mixed parabolic-hyperbolic type.] Vestnik Samarskogo gosudarstvennogo universiteta. Estestvennonauchnaia seriia - Bulletin of Samarskii State University. Naturally scientific. series., 8(89), 108-117 [in Russian].

19 Yuldashev, T.K., \& Kadirkulov, B.J. (2020). Boundary value problem for weak nonlinear partial differential equations of mixed type with fractional Hilfer operator. Axioms, 9, 2(68), 1-19. https://doi.org/10.3390 /axioms9020068

20 Yuldashev, T.K., \& Kadirkulov, B.J. (2020). Nonlocal problem for a mixed type fourth-order differential equation with Hilfer fractional operator. Ural Math. J., 6, 1, 153-167. http://dx.doi.org/10.15826/umj.2020.1.013.

21 Berdyshev, A.S., Kadirkulov, J.B., \& Eshmatov, B.E. (2016). Boundary value problems for fourth-order mixed type equation with fractional derivative. Electronic Journal of Differential Equations, 2016, 36, $1-11$.

22 Dzhrbashian, M.M. (1996). Integralnye preobrazovaniia $i$ predstavleniia funktsii $v$ kompleksnoi oblasti [Integral Transforms and Representations of Functions in the Complex Domain]. Moscow: Nauka [in Russian].

23 Kilbas, A.A., Srivastava, H.M., \& Trujillo, J.J. (2006). Theory and applications of fractional differential equations. North-Holland Mathematics Studies, 204. Elsevier Science B. V., Amsterdam, XVI, 523. 